\title{
Mineralogical investigations in metallurgy as a contribution to the afirmation of industrial mineralogy in Serbia
}

\begin{abstract}
Industrial mineralogy is a part of mineralogy dealing with natural and synthetic minerals, raw materials, secondary raw materials, polymineral materials that originated from the production processes, etc. As applicable, it has been used in the refractories industry, ceramics industry, ferrous and non-ferrous metallurgy, cement industry and other industries. The work aimed at presenting its contribution to the affirmation of industrial mineralogy in Serbia through the results of mineralogical investigations obtained in ferrous metallurgy and copper metallurgy. A larger number of mineralogical investigations, carried out on the materials being characteristic for metallurgical processes and issues of ferrous metallurgy and copper metallurgy, have been stated in this work. Refractory bricks, various types of slag, final flotation waste, copper concentrate, etc. have been investigated. At the same time, the reasons and objectives of performed mineralogical investigations have been given. The results of mineralogical investigations have been shown in detail on two examples. The first are associated with the problems and material in ferrous metallurgy and the second with the material and problems in copper metallurgy. Firstly, the results of mineralogical investigations of casting powders have been shown. They have been investigated for verification of the quality and erosion of the alumographite entry nozzles, that occurred due to their effect. The investigations aimed at increasing the durability (resistance) of the alumographite entry nozzles being utilized in the process of continuous casting of steel. By increasing the durability of entry nozzles the production costs are reduced. The method of $X$-ray diffraction analysis (XRPD) has been used for investigating the mineralogical composition of casting powders. The results of studying the process of copper concentrate roasting in the fluo-solid reactor have been shown in the second example, with the aim of investigating the transformation degree of the primary ore minerals under various technological parameters. The input material (charge) and roasting products in the reactor (calcine) were investigated by various methods. The investigation results have shown that reactions of mineral transformations are not completed, i.e. they are developing only partially (12-22\%), which is the consequence of insufficiently long heating, unsuitable temperature or unfulfilled other parameters, such as for example, a nonuniform grain size. All stated mineralogical investigations and the results shown in this work gave a significant contribution to the affirmation of industrial mineralogy in Serbia.
\end{abstract}

Keywords: Mineralogical investigations, Metallurgy, Industrial mineralogy.

\section{INTRODUCTION}

Industrial mineralogy is applicable and it is present in the world to a great extent in various industrial branches. The development of the same was delayed in Serbia, but it was developed to less extent even on our territories [1-4]. The control of initial raw materials and finished products is unavoidable for the manufacture of refractory bricks. By introducing mineralogical investigations through microscopic, XRDP, Differential-thermal, thermogravimetric method and other, the use of industrial mineralogy began in the refractories industry. The

Author'address: ${ }^{1}$ Institute IMS a.d., Boulevard vojvode Mišića 43, Belgrade, Serbia, ${ }^{2}$ University of Belgrade, Technical faculty in Bor, V.J 12, Bor, Serbia

Received for Publication: 10. 04. 2014.

Accepted for Publication: 23. 07. 2014. mineralogical composition of bricks, grain size, grain disposition, presence of pores, binder and other characteristics were determined. Magnesite, chromium magnesite, sintermagnesite, forsterite and other refractory bricks were investigated. This was done with the view of production monitoring, obtaining the necessary characteristics and reaching brick quality intended for linings of metallurgical and other plants.

Soon, the mineralogical investigations have been applied in metallurgy too. In this way, the industrial mineralogy was slowly gaining importance in metallurgy [5-6].

Mineralogical investigations in ferrous metallurgy (iron and steel industry) included the determination of mineralogical composition of the agglomerate that was produced at the Sintering Plant and utilized for the production of iron at the Blast Furnace [7-8]. The agglomerate was investigated by optical method (reflected light). The present mi- 
nerals were determined, such as: magnetite, hematite, fayalite, silica glass and other minerals in accordance with agglomerate basicity [9]. These results were useful in managing the Blast Furnace process. For establishing the reason for reduced resistance (durability) of the steel ladle lining or big damages, the refractory bricks were mineralogically investigated after ladle exploitation [10]. At the same time, slags being formed in the ladle during its exploitation, were also mineralogically investigated [11]. The optical method (reflected light) was most often used for the investigation. For establishing the reason for reduced resistance (durability) or big damages, different measures were taken. Depending on the reason for reduced resistance (durability) and big damage that occurred, the refractory bricks having a more suitable composition and quality were changed and built-in, technological parameters were adjusted, and other things too.

At the same time, in copper metallurgy, the industrial mineralogy was gaining an increasing importance.

In the process of flotation enrichment and metallurgical processing of smelter slag from RTB Bor, in addition to copper concentrate, which is transported to purification, the resulting FFW (final flotation waste) appears, which is transported to compaction, and after that, it is deposited to the tailings. These dumps are large areas of degraded land, and they are permanrnt polluters of soil, water and air.To discuss the application of FFW in the manufacturing of new materials from the glass-ceramic group, besides elementary addition, phase and mineral composition were examuned as well as thermal properties (the temperature interval of sintering, plastic deformation and melting) whose knowledge is necessary for usage in the production of glass-ceramic.

Also, the kinetics of sintering of finale flotation waste (FFW) has been investigated at different heating regimes, in order to find optimum conditions for sintering to be performed without body deformation and with a minimum energy and time consumption. The samples were examined using: $X$ ray diffraction analysis (XRPD), X-ray fluorescent analysis (XRF) and thermo microscopy.

The results of mineralogical investigations of two specific examples, associated with application of industrial mineralogy in metallurgy, are presented in this study.

\section{RESULTS AND DISCUSSION}

At the Steel Plant, at the radial continuous caster, the process of continuous steel casting is very important. Alumographite nozzles, the so-called SEN (Submerge entry nozzle) and casting powder are used for continuous steel casting. In the process of continuous steel casting SEN protects steel from oxidation and provides a uniform flow from the tundish to the mold.

The casting powder also protects steel from oxidation and prevents the formation of non-metallic inclusions in steel. Providing protection, the casting powder and its slag are in contact with SEN. At the contact they have an impact on the outside wall of the SEN performing smaller or higher erosion. The erosion intensity depends on the casting powder composition. By using aggressive casting powders, the SEN erosion is increased and its durability (resistance) reduced.

Phase composition of casting powders has been determined by the polarization microscope (transmitted light) and by X-ray diffraction analysis (XRPD). Mineral composition of the casting powders SRD-1 and SRD-2 is presented in Table 1, and micro view of these two casting powders is shown in Figure 1 and 2. In the experiments, carried out by the application of investigated casting powders at the radial continuous caster, the SEN erosion was established, which occurred due to casting powder effect.

Casting powders, containing the wollastonite mineral in the mineralogical composition, caused a minor SEN erosion from casting powders without the wollastonite mineral. The decrease of SEN erosion, due to casting powder effect with wollastonite SRD-2 was about 2,5 times compared to SEN erosion caused by the effect of the casting powder SRD-1 without wollastonite (Fig. 3) [5].

The slag in the mold, originating from casting powder without wollastonite, is aggressive and brings about a stronger erosion impact on the wall of the alumographite SEN. By the selection and application of adequate casting powder, the durability of SEN is increased and the stability of the continuous casting process is achieved. At the same time, the possibility of big damage occurrence and creation of inclusions in steel is reduced.

Table 1 - Mineralogical composition of castimg powders SRD-1 and SRD-2

\begin{tabular}{|c|c|c|c|c|c|c|}
\hline & $\begin{array}{c}\text { Wollastonite } \\
\mathrm{CaOSiO}_{2}\end{array}$ & $\begin{array}{c}\text { Quartz } \\
\mathrm{SiO}_{2}\end{array}$ & $\begin{array}{c}\text { Calcined lime } \\
\mathrm{CaO}\end{array}$ & $\begin{array}{c}\text { Graphite } \\
\mathrm{C}\end{array}$ & $\begin{array}{c}\text { Fluorite } \\
\mathrm{CaF}_{2}\end{array}$ & $\begin{array}{c}\text { Hematite } \\
\mathrm{Fe}_{2} \mathrm{O}_{3}\end{array}$ \\
\hline SRD-1 & & + & + & + & + & + \\
\hline SRD-2 & + & + & & + & + & + \\
\hline
\end{tabular}




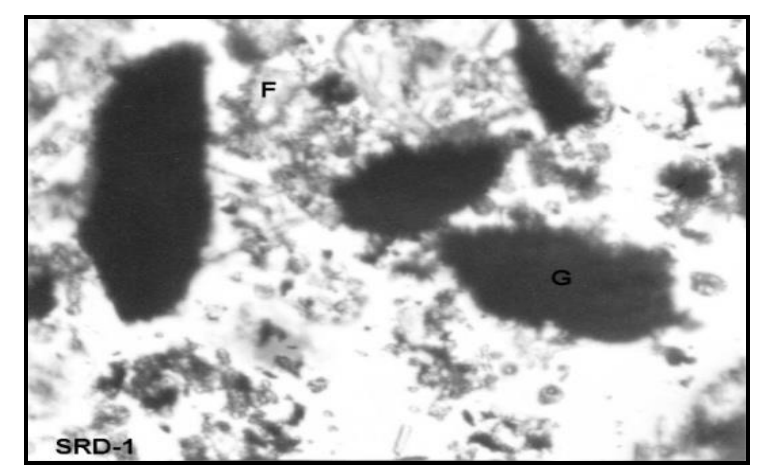

Figure 1 - Microphotos of casting powder SRD-1 (refracted light-immersion liquid, xilol), magnification x250 F-Fluorite, G-Graphite

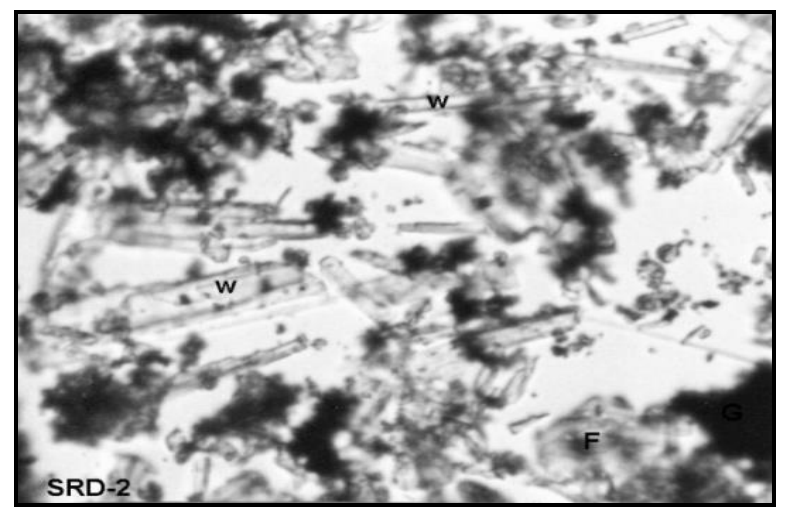

Figure 2 - Microphotos of casting powder SRD-2 (refracted light-immersion liquid, xilol), magnification x250, W- Wollastonite F-Fluorite,GGraphite

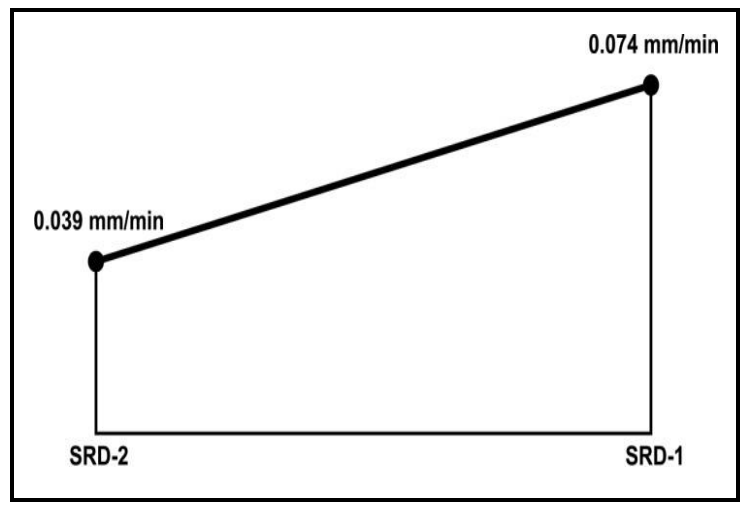

Figure 3 - Level average value erosion alumino graphite SEN usled casting powder SRD-2 with wollastonite and casting powder SRD-1 wihtout wollastonite (Devic dr. 2002)

The process of roasting sulphide concentrates of copper in the reactor with fluidization layer is a complicated physical-chemical process, and represents the first phase in the chain of processing copper concentrates in the Mining and Smelting Works in Bor, therefore, the importance of proper and high-quality process managing is understandable, as the prerequisite for correct processing in the following phases, and finally for high-quality cathode copper as well.

The essence of the process is in heating the material in an appropriate atmosphere and up to determined temperature, at which melting does not occur, aiming at changing the mineral composition of the concentrate. Concentrates are the basic raw material necessary for operation of the Smelting Works. They must have a uniform chemical, granulometric and mineral composition.

Mixed with the fluxing agent in defined ratio, they make a charge being transported by the conveyor system for roasting in the fluo-solid reactor. In the process of charge roasting, the mineral composition is apparently changed. Pyrite and a portion of chalcopyrite are dissociated and converted to more stable sulphides of copper and iron: bornite, pyrrhotite and magnetite, while a portion of chalcopyrite, at roasting, remains unchanged, because there is no sufficient time for its complete transformation.

Incomplete transformation not only disrupts the technological process, but also has environmental importance - a higher portion of sulphur does not go to the sulphuric acid plant, but is released in the environment by polluting it. For those reasons, the optimization of production is necessary, as well as permanent control of input and output (of charge and calcine). Phase composition of calcine has been determined by the polarization microscope (reflected light) and X-ray diffraction analysis (XRPD).

The diffractograms of calcine, treated at different temperatures, are shown in Figure 4.

With temperature increase, chalcopyrite $\left(\mathrm{CuFeS}_{2}\right)$ content decreases, and magnetite $\left(\mathrm{Fe}_{2} \mathrm{O}_{3}\right)$ and bornite $\left(\mathrm{Cu}_{5} \mathrm{FeS}_{4}\right)$ content increases.

Based on the obtained results of chemical and mineralogical analysis of copper roast it could be concluded that, during the roasting in the fluidized bed reactor, transformation of chalcopyrite, is not follow the model of spherical zonarity.

The obtained results show that mineralogical transformations do not proceed from periphery to the center of the grain, but in the form of laminar separations. This is ilustrated in the microphotos, given in Figure 5 [6].

Reactions of mineral transformations are not complete, i.e. they are only partly developed (12 $22 \%$ ) what is the result of insufficient time, unsuitable temperature or unfilling the other parameters as well as for example a grain size.

Uncomplete transformation disturbs both the technological process and has ecological importance due to a fact that a large part of sulphur does 
not go to the Sulphuric Acid Plant but into the vicinity and polluts it. Due to those reasons, a pro- duction optimization is required as well as permanent control of Charge and Calcine.

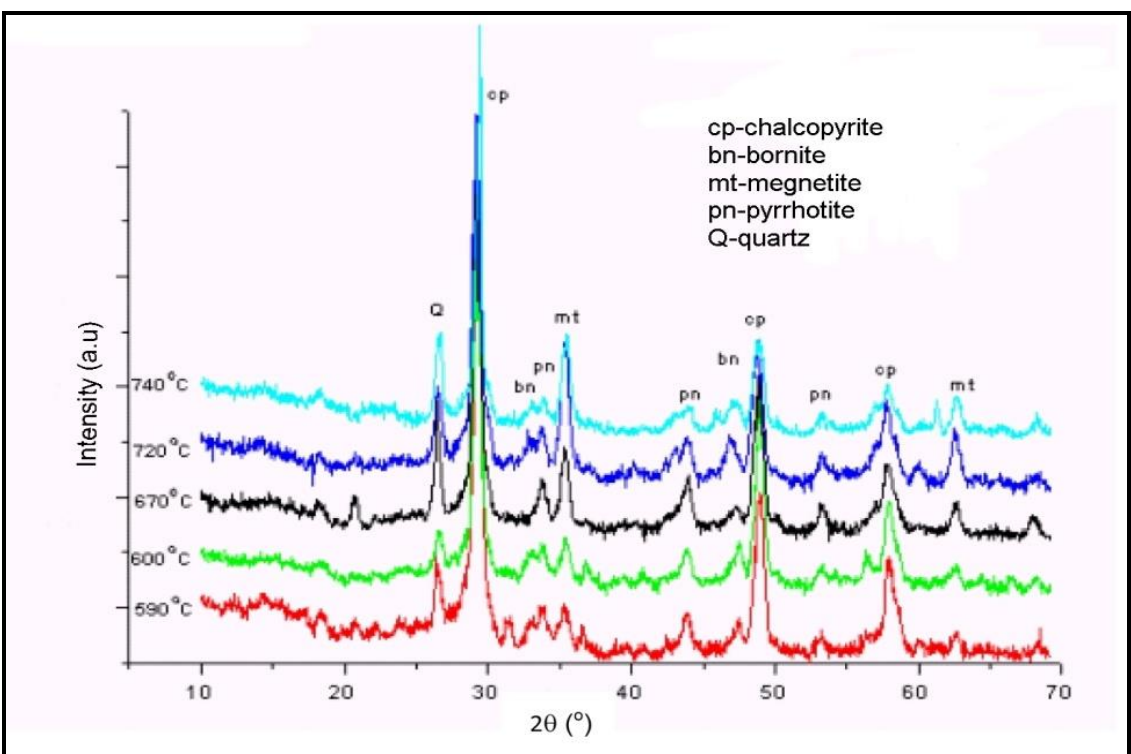

Figure 4 - Diffractogram of Calcine samples at various temperatures: $590^{\circ} \mathrm{C}, 600^{\circ} \mathrm{C}, 670^{\circ} \mathrm{C}$, $720^{\circ} \mathrm{C}$ and $740^{\circ} \mathrm{C}$
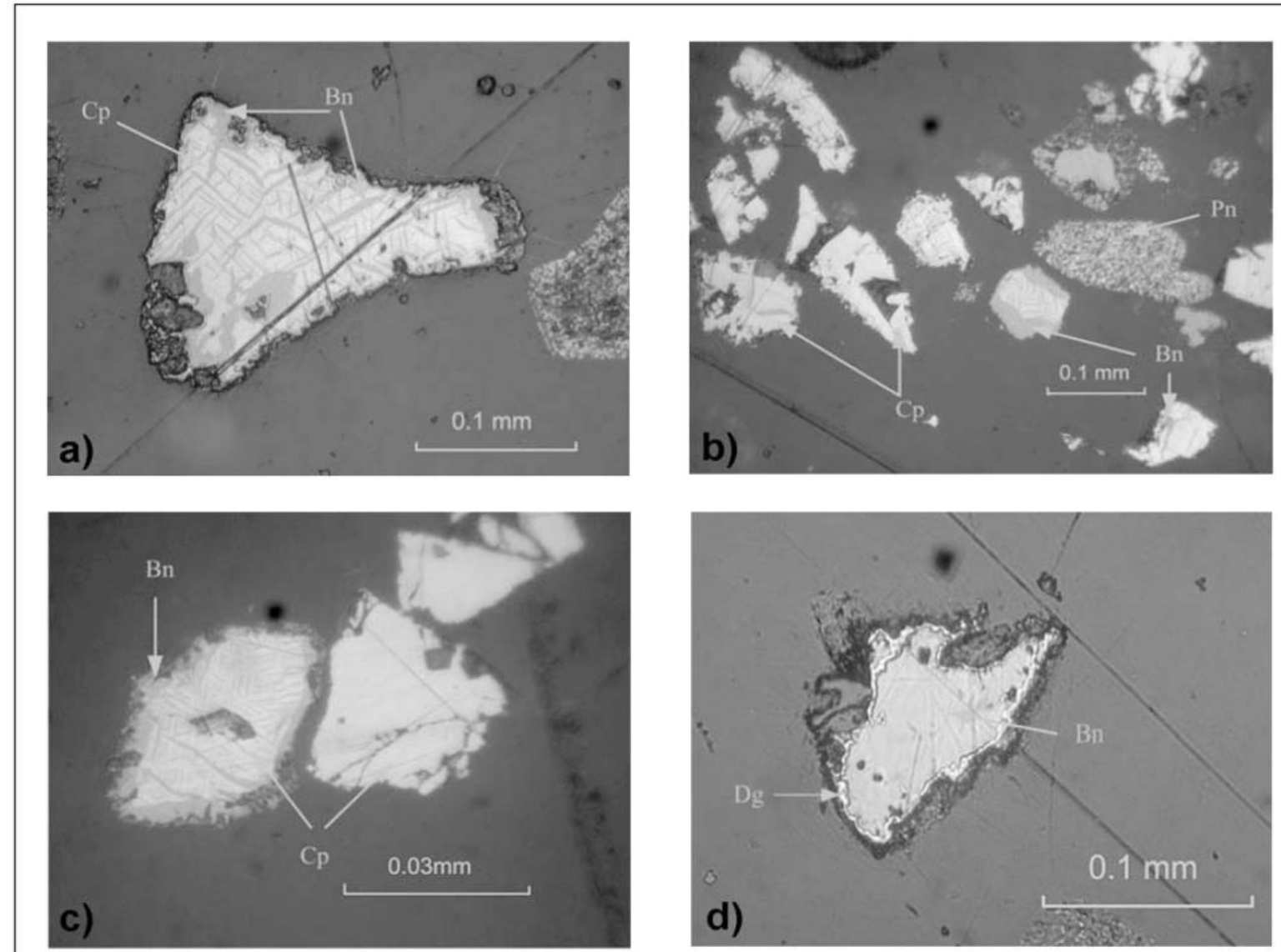

Figure 5 - Microphoto of: a) chalcopyrite (Cp) with separation of bornite $(B n)$ in sample Calcine 1 , b) chalcopyrite $(C p)$, pyrrhotite $(P n)$ and chalcopyrite with separation of bornite $(B n)$ in sample Calcine 1 , c) chalcopyrite $(C p)$ and chalcopyrite with separation of bornite $(B n)$ in sample Calcine $1, d)$ bornite (Bn) with an edge of digenite $(D g)$ in sample Calcine 1, (granulometric fraction $+0.075 \mathrm{~mm}$.) 


\section{CONCLUSION}

On the basis of a brief presentation of the results of mineralogical investigations, carried out on the materials being used or obtained in the ferrous metallurgy process and copper metallurgy, a contribution to the affirmation of industrial mineralogy in Serbia is evident.

Diversity of materials, various aggregates, specific characteristics of metallurgical processes and problems in metallurgy provide a great opportunity for researchers' work in the area of industrial mineralogy, and thereby its further and greater affirmation.

\section{REFERENCES}

[1] S.Dević, R.Galjak, L.Todorović, Troske iz livnog lonca nastale pri upotrebi kisele i bazne prekrivke, 2001, V Jugoslovensko savetovanje metalurga Jugoslavije, Novi Sad, (2001) 111

[2] S.Dević, Mineralogical - Chemical characteristics and slag minerals morphology in the SARTID's Steel plant, $11^{\text {th }}$ International metallurgy \& materials congress, Istanbul, Turkey, (2002) p. 46

[3] M.Cocić, M.Logar, S.Cocić, S.Dević, B.Matović, D.Manasijević, (2007) Mineralogical transformations in copper concentrate roasting in fluo-solid reactor, Journal of Mining and Metallurgy, 43B, 1, 71 - 84

[4] M. Cocić, M. Logar, B. Matović, S. Dević, Mogućnosti primene flotacijske jalovine RTB Bor, 5 Simpo- zijum "Reciklažne tehnologije i održivi razvoj" sa međ. učešćem, Soko Banja, (2010) p.104-109

[5] S.Devic, I.Zivojinovic, R.Carli, G.Faraveli, SEN wearing - experimental evidences of strong casting powder effect, $4^{\text {th }}$ European Continuous Casting Conference, International Convention Centar, Birmingham, UK, (2002) pp. 932-938

[6] M. Cocić, M. Logar, S. Cocić, S. Dević, and D. Manasijević, (2011) Transformation of Chalcopyrite in the Roasting Process of Copper Concentrate in Fluidized Bed Reactor, JOM 05,Vol.63, 55-60,

[7] S.Dević, Mineralni sastav i morfologija minerala sintera, 8. Kongres inženjera i tehničara - Beograd, (1997) p.138 - 140

[8] S.Dević, D.Gligorić, Varijacije u mineraloškom sastavu sintera, 29. Borsko savetovanje rudara i metalurga - Borsko jezero, (1997) p.431 - 435

[9] S.Dević, Minerali aglomerata, eksploatisanih vatrostalnih materijala i produkata proizvodnog procesa Sartida identifikovani metodom rudne mikroskopije, 13. Kongres geologa Jugoslavije - Herceg Novi, (1998) p.1 - 6

[10] S.Dević, Pregled izdržljivosti ozida livnih lonaca i promene nastale na maghromitnim opekama, 30. Borsko savetovanje rudara i metalurga, Donji Milanovac, (1998) p.521 - 525

[11] S.Dević, V.Bojković, Z.Cvetković, J.Danilović, Karakteristike troske pre i posle vanpećne obrade, 13. Kongres geologa Jugoslavije - Herceg Novi, (1998) p.417 - 424

\section{IZVOD}

\section{MINERALOŠKA ISPITIVANJA U METALURGIJI KAO DOPRINOS AFIRMACIJI INDUSTRIJSKE MINERALOGIJE SRBIJE}

Industrijska mineralogija predstavlja deo mineralogije koja se bavi prirodnim i sintetičkim mineralima, sirovinama, sekundarnim sirovinama, polimineralnim materijalima, koji su nastali u procesima proizvodnje. Kao aplikativna ona je našla svoje mesto u vatrostalnoj industriji, keramičkoj industriji, crnoj i obojenoj metalurgiji, cementnoj industriji i drugim industrijama. Rad ima za cilj da kroz rezultate mineraloških ispitivanaja dobijenih u crnoj metalurgiji i metalurgiji bakra pokaže njihov doprinos afirmaciji industrijske mineralogije Srbije. U radu je naveden veći broj mineraloških ispitivanja obavljenih na materijalima koji su karakteristični za metalurške procese $i$ problematiku crne metalurgije $i$ metalurgije bakra. Ispitivane su vatrostalne opeke, različite troske, definitivna flotacijska jalovina, koncentrat bakra, itd. Istovremeno su dati razlozi $i$ ciljevi obavljenih mineraloških ispitivanju. Detaljno, na dva primera, prikazani su rezultati mineraloških ispitivanja. Jedni su vezani za problematiku i materijal u crnoj metalurgiji, a drugi za materijal i problematiku u metalurgiji bakra. Prvim su prikazani rezultati mineraloških ispitivanja livnih prahova. Ispitani su radi provere kvaliteta i erozije alumografitnih izlivnika nastale usled njihovog dejstva. Ispitivanja su imala za cilj povećanje trajnosti (izdržljivosti) alumografitih izlivnika koji se koriste u procesu kontinuiranog livenja čelika. Povećanjem trajnosti izlivnika smanjuju se troškovi proizvodnje. Za ispitivanje mineraloškog sastav livnih prahova korišćena je metoda rendgensko difrakcione analize (XRPD). U drugom primeru prikazani su rezultati proučavanja procesa prženja koncetrata bakra u fluo-solid reaktoru sa ciljem da se ispita stepen transformacije primarnih rudnih minerala pod različitim tehnološkim parametrima.Ulazni materijal (šarža) $i$ produkti prženja u reaktoru (poletina) ispitivani su različitim metodama. Rezultati ispitivanja su pokazali da reakcije transformacija minerala nisu potpune tj. odvijaju se samo delimično (12-22\%); što je posledica nedovoljno dugog zagrevanja, neodgovarajuće temperature ili neispunjenosti drugih parametara kao što je npr. neujednačena veličina zrna. Sva navedena mineraloška ispitivanja $i$ rezultati prikazani u ovom radu dali su značajan doprinos afirmaciji Industrijske mineralogije Srbije.

Keywords: Mineraloška ispitivanja, Industrijska mineralogija, metalurgija

Pregledni rad

Primljeno za publikovanje: 10. 04. 2014.

Prihvaćeno za publikovanje: 23. 07. 2014. 